\title{
On the Same Page? A Content Analysis of President Trump's 2018 Tweets Regarding Issues Most Relevant to the American People
}

\author{
Yolanda Denise Campbell \\ Southern University and A\&M College, Baton Rouge, Louisiana, USA \\ (iD) 0000-0002-4279-2283 \\ ÐYolanda_Campbell@subr.edu
}

\author{
ARTICLE INFO \\ Received: 18 June 2019 \\ Accepted: 31 July 2019 \\ Published: 29 August 2019 \\ DOI: https://doi.org/10.29333/ojcmt/5901
}

ABSTRACT

Through a content analysis of President Donald Trump's 2018 tweets, results revealed that his most prominent tweets were about the Mueller probe/Russia investigation, a topic which polled as one of the least important issues to the American people in a 2018 poll given by NBC News/Wall Street Journal. Although the results reveal that what the President deemed as most important didn't match rank wise with the American people, everything he tweeted about was issues included in the 2018 poll-a strong indication of agenda-setting occurring between Trump's tweets and the minds of the American people. In addition to frequency of tweets, Trump's stance/tone regarding the poll topics were examined. Those findings showed that during natural disasters and mass shootings, the President offered some moments of consoling to the nation, but they were not absent of malice. Additionally, Trump's tweets heavily criticized and questioned the validity of the Mueller investigation, bolstered his way of handling the economy, immigration, and trade and criticized any and all whose words and/or actions were in opposition to him and/or his administration.

Keywords: President Donald Trump, Twitter, content analysis, agenda-setting theory, political communication, Russia investigation

\section{INTRODUCTION}

Infamous for his use of the social media account Twitter to win the 2016 election against Democratic candidate Hillary Clinton, President Donald Trump has continued to use the medium while in office to communicate his agenda for the country and everything else in between (Johnson, 2018). Since his communication with the American people is largely via his Twitter account in leu of the traditional media, Trump's tweets have become the subject of many studies in the field of communication on various fronts (Keith, 2016). Most studies have been an examination of how his tweets have influenced and driven the stories appearing in traditional news media. Some have looked at how he has used the platform to attack his political opponents and/or what he has said about singular topics/events. However, few studies have examined and compared the influence of what President Trump says and its possible influence on the American people as it is a large and somewhat allusive thing to effectively measure outside of an election result which yields evidence of the people's support for a particular candidate. Nonetheless, this study attempts to contribute to the expanding political communication literature regarding the Copyright (C) 2019 by OJCMT 
growing usage of social media in politics and particularly how one of Twitter's greatest influencers, President Trump uses the medium to maneuver through his presidency and the various issues facing the American people. Consequently, this study will specifically focus on President Trump's 2018 tweets. Particularly, it will utilize the results of a 2018 NBC News/Wall Street Journal poll that gauged the opinions of both Democrats, Republicans, and Independents in pursuit of the issues/topics they saw as most prevalent to them in 2018 (Dann, 2018). The poll's resulting topics will be used to compare with the content of President Trump's tweets made about those said events. As a result, we will be able to see if there's a correlating relationship between the tweets/agenda of the President and that of the people. Were the issues seen as prevalent by the American public in 2018 synonymous to the President's tweets and what was his stance on those issues? A collection of Trump's 2018 tweets concerning the issues/topics that resulted from the NBC/Wall Street Journal poll were obtained from his twitter page. Those topics included: the improving economy/record low unemployment rate, major mass shootings, separation of families/immigrants seeking asylum, natural disasters, the year of the woman in Congress, major tariffs and trade negotiations, the Mueller probe, and The MeToo Movement.

\section{LITERATURE REVIEW}

This review of literature was based upon research that explains the theoretical grounding of this study as well as previous research about the role that social media plays in politics. The studies reported examine agenda-setting theory and how social media, much like traditional media, can be viewed through the lens of agenda-setting.

\section{Agenda-Setting Theory}

Agenda-Setting is one of the most frequently cited theories in the field of mass communication as it relates to the study of mediated communication. The theory asserts that the media sets the agenda because it tells the public what to think about by what they select to include in their pages and/or broadcast via television or radio. This is important because the stories chosen by traditional media can possibly influence public opinion and ultimately affect peoples' behaviors. Researchers McCombs and Shaw (1972) believed that agenda-setting explained the correlating relationship between the media and the public ordering of priorities and that likewise the public can also impact the media.

In addition to being applied to the study of traditional media, in the last decade, the study of alternative media such as social media has also been grounded in agenda-setting theory. Parmelee's (2013) study takes a closer look at the agenda-building function of politics via social media and particularly how it has come to influence traditional news media. In the article, the author obtains in-depth interviews with actual political reporters and editors at several U.S. newspapers during the 2012 campaign season. Results show that most of the reporters interviewed expressed how they relied heavily on Twitter, particularly the tweets from political leaders, to inform what they wrote about and how they framed their news stories. The article provides a unique insight into the minds/decisions of reporters and/or editors who serve as the gatekeepers to the traditional media being prompted by social media and its influencers.

Agenda-setting articles about the influence of social media often examine the posts being made by a single person and/or interactions/reactions of the followers in response to said posts (Alonso-Muñoz \& Casero-Ripollés, 2018; Lee \& Xu, 2018; Perez-Curiel \& Naharro, 2019). In the realm of politics that equates to examining politicians' 
posts/messages on social media and/or the interaction of the politician with his/her followers and/or the interaction amongst followers with each other. Additionally, some studies try to examine the impact the politician's agenda has on potential voters' opinions and/or behaviors.

\section{Trending: The Use of Social Media in Politics and Trump's use of Twitter}

In order to understand the significance and correlation of Trump's tweets/agenda and what he sees as important, this literature review is meant to further clarify the significant role that social media currently plays in politics and offers some background as to how Trump has previously utilized Twitter as a major political communication platform.

Currently, over a dozen Democratic Presidential Candidates have entered the race to run toe to toe with President Donald Trump in 2020. Many have made formal announcements already, which has included either a traditional press conference and/or televised kick-off rally, but many have also opted to utilize social media whether YouTube, Facebook, Instagram, etc. to speak to the American people to make the case of why they should be the next President of the United States of America.

According to Pérez-Curiel and Naharro (2019), political candidates have really recognized the role social media can play in advancing their platforms. In fact, they suggest that the personality of political candidates has grown increasingly into a brand image and that social media has been a necessary avenue to tap into in order to resonate with the changing ways in which people consume news and information. The article shows just how influential social media can be by exploring the tweets of President Trump during his first 100 days in office. Results revealed that the content of Trumps tweets set the agenda for what was seen on the front pages of traditional media such as The USA Today, The Boston Globe, The Wall Street Journal and The New York Times. Trump's tweets drove the news cycle of discussion across the country-he said it, they reported it. Thus, the article confirmed Trump's empowerment on Twitter as a main source of news and recognized him as a great political influencer. It also elevated just how instrumental the Twitter platform can be in establishing agenda-setting in terms of influencing traditional media and ultimately Twitter followers who liked and retweeted specific topics posted by Trump.

Anderson's (2017) article also talked about the Trump effect when it referenced Donald Trump as "Tweeter-in-chief" and named him one of the most prolific Twitter users in politics who tweets an average 7.5 times per day. Through a content analysis of Trump's tweets during his first seven months in the Oval Office, the study found that he often criticized members of Congress, showed an overwhelming support of Fox television shows by retweeting them, and seemed very vocal in criticizing the press. The study also showed how Trump utilized Twitter as a controlled platform to disseminate a substantive amount of political issues because he didn't feel like the mainstream media offered a fair opportunity to him.

However, nothing speaks more clearly about the power of social media than President Donald Trump's winning of the 2016 Presidential election. According to Johnson (2018), leading up to the 2016 election, President Trump primarily used Twitter to win the presidency and no one saw it coming, not even the pollsters. Trump won in areas and states where the other candidate spent more time and campaign advertisement dollars. The article argues that Trump used Twitter as what they called a "disruptive technology"-meaning it was not being used by many of the other candidates at the time and he interrupted the usual process/practice of politics. Interestingly, the author points 
out that Trump's Twitter win follows in the footsteps of some other prominent politicians who also became president because of disruptive technologies-Franklin D. Roosevelt, John F. Kennedy, and Barack Obama. Each of those Presidents introduced how a new and untraditional medium could be used to communicate with the American people. Roosevelt utilized radio, Kennedy employed the medium of television, and Obama made strategic use of the Internet. Although Obama utilized the popular social mediums of the time such as YouTube, Facebook, and even Twitter, it was not nearly to the magnitude of Trump. The author asserts that it was Trump's personalization of Twitter, often drafting his own fiery tweets that were in likeness with his controversial rallies that drew in millions and millions of followers and ultimately landed him (against all odds) into the White House. Trump's tweets became his actual words and not that of campaign aides making posts and the American people seemed to identify with that new tactic. Thus, Trump along with Roosevelt, Kennedy and Obama were all the first candidates to revolutionize new mediums to better connect with their voters.

In order to assess the continued usage of social media (Twitter) by President Trump in correlation with the top issues on the minds of the American people for 2018, the following research questions were proposed:

Research Questions

RQ1 How did the frequency/order of importance of Trump's tweets compare with the results of the NBC/Wallstreet Journal's 2018 poll?

RQ2 Which topic did President Trump tweet about most in 2018?

RQ3 What was President Trump's stance regarding the eight topics stemming from the 2018 NBC/Wallstreet Journal poll?

\section{METHODOLOGY}

In order to answer and assess those research questions, this study conducted a content analysis of President Donald Trump's tweets for 2018. Specifically, his tweets that discussed the top eight most important issues that appeared in the 2018 NBC News/Wall Street Journal poll were examined: the improving economy/record low unemployment, mass shootings, the separation of families/immigrants seeking asylum, natural disasters, the year of the woman in congress, tariffs and trade negotiations, the Mueller probe, and the MeToo movement.

As previously stated, the 2018 NBC News/Wall Street Journal poll was selected as a benchmark in deciding what Trump tweets to gather/analyze. According to Dann 2018, the poll of 900 adults was conducted in December of 2018. A variety of political viewpoints were ascertained in that sample which included the opinions of Democrats, Republicans, and Independents.

\section{Content Analysis}

Content analysis is the specific method of analysis being used in this study as it was used by several other studies included in the literature review which examined the use/impact of social media. It is a systematic process that examines the characteristics of communication messages. The purpose is to learn something about the content and those who produced the messages. Mainly considered to be a quantitative method for researching messages, it largely allows us to break up the information we have obtained from a speech, interview, or a tweet into units that can be placed into categories that can be counted (Stacks, 2011). These categories may include words, characters, physical measures of time and space, and items. However, there is an element of content analysis 
called the theme and/or thesis, this is a unit of analysis that explores a deeper meaning of a message. Thus, it is not easily seen and/or countable like the words of a speech. Yet, it can lend more of a qualitative look at some emerging themes in the text that may answer why and/or how. Thus, Trump's 2018 tweets were selected as a unit of analysis. The specific units examined were the number of tweets for each event/topic, the emerging theme/thesis of the tweet, and the stance taken by Trump regarding the theme/thesis. How many times Trump tweets about a given topic will provide helpful insight to what he saw as important. Likewise, what he says in his tweet, the emerging theme/stance will also add more depth to what and why he was tweeting about certain topics.

An advanced search via Twitter was completed from @therealdonaldtrump, the official account of President Donald J. Trump. The search criteria for tweets about the top 2018 stories included Trump's account name, key phrases or words associated with the topics/event, the specific date of the topics/event and at least two weeks after the event.

Once the tweets were collected to note frequency and the emerging themes/thesis, the language used in Trump's tweets were examined to determine his tone/stance regarding the various topics. Did Trump speak positively, negatively, and/or neutrally regarding leading figures and/or subjects/topics? Once all tweets were collected, the researcher read and listed the emerging themes per event. Afterwards, the stance of the themes was established, which was derived at through a pre-cursory review of the tweets. To ensure reliable stances were being made intercoder reliability was tested regarding the stance taken by Trump in the tweets. Two coders were given a sample of a minimum 8 tweets per topic as that was the lowest number of tweets found during one event. Thus, a total of 64 tweets were given to the coders to categorize Trump's stance on each topic.

A 94\% agreement between the coders was founded. Below is a list which details each event searched for, the time frame examined and/or the keywords utilized in the search.

\section{Topics and Timeframe of Tweets Collected}

The following is the specified timeframe of collection/analysis for each event derived from the 2018 NBC News/Wall Street Journal Poll and a list of the keywords used to search President Trump's tweets via his Twitter account page--@realdonaldtrump.

Improving economy/record low unemployment

According to the Bureau of Labor Statistics, the national unemployment rate is usually released during the first week of the month ("Bureau Labor," 2019). Thus, tweets during the first two weeks of April and September were examined. April 2018 was initially selected because it represents the first time in the president's tenure that unemployment rate dropped below $4 \%$ to $3.9 \%$ and the other notable time was September of 2018 - this time represents the lowest 2018 unemployment rate. However, because those specific dates yielded so little tweets, the entire year of 2018, from January to December was examined for tweets regarding the economy/low unemployment. Keyword search included the terms: record low unemployment, improving economy, bureau of labor and statistics, economy, and jobs.

\section{Mass shootings}

The time frame of tweet analysis for each major mass shooting of 2018 was the day of the shooting and at least two weeks after.

Stoneman Douglas High School in Parkland, Florida. February $14^{\text {th }}-28^{\text {th }}$. 
Keyword search included the terms: Stoneman Douglas Parkland Florida, shooting, gunman, prayer, victims, and families.

Santé Fe High School shooting in Santé Fe, Texas. May 18 $8_{\text {th_June } 1^{\text {st }} .}$

Keyword search included the terms: Santé Fe High School, Texas, shooting, gunman, prayer, victims, and families.

Tree of Life Synagogue shooting in Pittsburg, Pennsylvania. October 27th-November $10^{\text {th }}$.

Keyword search included the terms: Tree of Life Synagogue Pittsburg Pennsylvania, anti-Semitic, Jews, shooting, gunman, prayer, victims, and families.

Borderline Bar and Grill shooting in Thousand Oaks, California. November $7^{\text {th }}-21^{\text {st }}$.

Keyword search included the terms: Borderline Bar and Grill Thousand Oaks California, shooting, gunman, prayer, victims, and families.

Separation of families/immigrants seeking asylum

The major happenings of this time period included the Trump administration's launch of its "zero tolerance" 1 policy on the southwest border on April $6^{\text {th }}$, President Trump's signing of an executive order on June $20^{\text {th }}$ to stop the separation of children from their families, the death of the first child detained by the border patrol on December $8^{\text {th }}$ and the death of the second child detained by the border patrol on December $24^{\text {th }}$. Although an enormous amount of controversy was ongoing from April to the end of the year regarding patrol of the southern border, this study continued with the two weeks after a major event as a timeline of analysis. Therefore, tweets from April $6^{\text {th }}$-April 20 th; June 20th July $4^{\text {th }}$; December $8^{\text {th }}$ December 22nd; and December 24th to December $31^{\text {st }}$ (since this is last day of the year and study is based on 2018 tweets December $31^{\text {st }}$ was last day of tweet analysis even though this only yields one week after the event analysis). Keyword search included the terms: separation of families, illegal immigrants, undocumented, separation children, southwest border, zero tolerance, and asylum.

\section{$\underline{\text { Natural disasters }}$}

The time frame of tweet analysis for each natural disaster was the day of the disaster and at least two weeks after.

Hurricane Florence-September $14^{\text {th }}-28^{\text {th }}$. Keyword search included the terms: Hurricane Florence, North Carolina, disaster, recovery, FEMA, South Carolina, first responders, and law enforcement.

Hurricane Michael-October $10^{\text {th }}-24^{\text {th }}$. Keyword search included the terms: Hurricane Michael, Florida, disaster, recovery, FEMA, Georgia, first responders, and law enforcement.

California Wildfires-November $8^{\text {th }}-22^{\text {nd }}$. Keyword search included the terms: California, wildfires, disaster, Campfire, Woolsey fire, FEMA, firefighters, burn, and forest management.

\footnotetext{
${ }^{1}$ The "zero tolerance" policy gave the Justice Department and border authorities the power to prosecute every adult who crossed the southwest border illegally. Because of this policy, children who crossed the border with adults were separated from their families because children could not be detained for extended periods of time like the adults. It is estimated that over 2,300 children were separated from their parents from October 2017 to the end of June 2018 (Hegarty, 2018)
} 


\section{The year of the woman in congress}

The time frame of tweet analysis for the year of the woman ${ }^{2}$ in congress spans from election day to two weeks after. November $6^{\text {th }}-20^{\text {th }}$. Keyword search included the terms: congress, women, mid-term elections, Senate, House of Representatives, Democrats, and Republicans.

\section{Tariffs and trade negotiation}

Some of the most notable tariffs and trade negotiations ${ }^{3}$ occurred from June $1^{\text {st }}$ August $30^{\text {th }}$. Keyword search included the terms: tariffs, trade, negotiation, China, Mexico, South Korea, India, Australia, Brazil, and European Union.

\section{The Mueller probe}

The time frame of analysis of the Mueller probe/Russia investigation ${ }^{4}$ was two weeks after the major occurrences of 2018 centering around the charging of Michael Cohen, Paul Manafort and the Russians.

Cohen-House Raided on April 9th; August 21 $1^{\text {st }}$-Cohen pleads guilty to eight counts including tax evasion and making false statements to a financial institution. Also implicates making payment to porn star Stormy Daniels at the direction of Trump (Individual 1); Nov. $29^{\text {th }}$ Cohen pleads guilty to making false statement to Congress regarding the infamous meeting about Trump Tower in Moscow; and on Dec. 12 $2^{\text {th }}$, Cohen is sentenced to three years in federal prison (Rodriguez \& Jin, 2018). Two weeks of tweets after each major Cohen date was examined. Therefore, the specific time frame of analysis for tweets regarding Cohen were April 9 $9_{-}^{\text {th }} 23^{\text {rd }}$; April $21^{\text {st }}$ May $5^{\text {th }}$; November $2^{\text {th }}$-December $13^{\text {th }}$; and December $12^{\text {th }}-26^{\text {th }}$. Keyword search included the terms: Michael Cohen, lawyer, Russia, Robert Mueller Probe, Russia, and investigation.

Manafort-Found guilty of eight charges of bank and tax fraud on August 21st; On September $14^{\text {th }}$-Manafort pleads guilty to two counts of conspiracy and agrees to cooperate with the Mueller investigation; On November $26^{\text {th }}$, Manafort was accused of breaching his cooperation agreement with special counsel and lying (Beavers \& Thomsen, 2019; Levine, 2019). Two weeks after each major Manafort date were examined. Therefore, the time frame of analysis was August 21 st_-September $4^{\text {th }}$; September $14^{\text {th }}-28^{\text {th }}$; November $26^{\text {th }}$-December $10^{\text {th }}$. Keyword search included the terms: Paul Manafort, campaign manager, Russia, Robert Mueller Probe, and investigation.

Russian Social Media Interference-13 Russians and 3 entities were indicted on February 16, 2018, for allegedly utilizing social media to influence the 2016 election. 12 officials from the Russian government's military intelligence unit were also indicted on June 13, 2018 for allegedly hacking the Democratic National Convention

\footnotetext{
${ }^{2}$ Year of the Woman. The Pew Research Center asserts that the $116^{\text {th }}$ Congress elected on November 6, 2018, represents the biggest jump in women members since the 1990s. A record 102 women were elected to serve in the House of Representatives (Desilver, 2018)

${ }^{3}$ Tariffs and trade negotiation. A trade war of sorts began in June of 2018 when the U.S. proposed/imposed a series of tariffs on a variety of products including steel and aluminum. The tariffs affected several countries including China, Mexico, Canada, South Korea, India, Australia, Brazil, and the European Union. The most notable retaliation tariffs have occurred between the U.S. and China ("Tariff Timeline," 2019)

${ }^{4}$ Mueller probe/Russia investigation was launched in 2017 to investigate whether Russia interfered and/or conspired with the Trump campaign in the 2016 U.S. presidential election. Criminal charges were brought against several defendants some from the Russian camp and some who were associated with President Trump's inner circle. Two of those key figures closest to Trump who were charged included-Paul Manafort, Former Trump campaign chairman and Michael Cohen, Former Trump Lawyer (Levine, 2019)
} 
computers (Beavers \& Thomsen, 2019; Levine, 2019). Two weeks after each date were examined. Therefore, the time frame of analysis was February $16^{\text {th }}$-March $2^{\text {nd }}$ and June $13^{\text {th }}-27^{\text {th }}$. Keyword search included the terms: Russian(s), social media, 2016 election, influence, Russian government, Vladimir Putin, and interference.

\section{The MeToo movement}

Although the MeToo movement ${ }^{5}$ has been ongoing since 2017, four specific happenings during this period were examined: tweets regarding the January 20th Women's March on Washington, the September 27th Kavanaugh and Dr. Christina Blasey Ford's testimony ${ }^{6}$, the October 6th Supreme Court Brett Kavanaugh confirmation vote, and the December 12 th House/Senate agreement ${ }^{7}$ to change old rules regarding sexual harassment and discrimination on Capitol Hill. Like the previous happenings, tweets two weeks after each event was examined. Thus, the specific times of analysis are January $20^{\text {th }}$-February $3^{\text {rd }}$; September 27-October $11^{\text {th }}$; October 6-October 20 $0^{\text {th }}$ : December $12^{\text {th }}-26^{\text {th }}$. Keyword search included for topics about Kavanaugh and Dr. Ford included: Brett Kavanaugh, Dr. Christian Blasey Ford, Supreme Court Justice Nominee hearing, sexual harassment, sexual assault, and me too movement; for the Women's March keyword search included the terms: Women's march, protest, rights, inauguration anniversary, and me too movement; and for the House/Senate Agreement keyword search included the terms: sexual harassment, sexual assault, House, Senate, agreement, discrimination, and me too movement.

\section{RESULTS}

\section{RQ1 How did the Frequency/Order of Importance of Trump's Tweets}

Compare with the Results of the NBC/Wallstreet Journal's 2018 poll?

A total of 359 tweets were collected and examined and as Table 1 reveals, Trump's most frequent tweets were not in exact agreement with the top issues most prevalent to the American people even though he tweeted about all the eight topics. There was only one topic that shared the same rank in terms of importance for both Trump and the American people-natural disasters. Additionally, the top three topics didn't align. However, two of the topics emerged as most important to both Trump and the people-the economy and the separation of families. If previous research has shown that Trump influences the media and journalists and acknowledge that they utilize social media and particularly tweets of social media influencers for story ideas (Parmelee, 2013), it is not at all unreasonable to conclude that Trump's tweets could've definitely influenced the top eight

\footnotetext{
${ }^{5}$ The MeToo Movement began in 2017 after the calling out of Harry Weinstein, a high-level Hollywood executive, for sexual misconduct and rape by a host of women in Hollywood. The hashtag/movement catalyzed a firestorm of public conversation and media coverage of the issues that women face in the workplace at the hands of men. Additionally, the atmosphere regarding sexual harassment against women became such an awesome one that it found itself front and center in the political arena also, specifically in Washington, D.C. (Johnson \& Hawbaker, 2019)

${ }^{6}$ Kavanaugh and Dr. Christina Blasey Ford testimony. Trump's Supreme Court Nominee Brett Kavanaugh was accused of sexually assaulting Dr. Christine Blasey Ford while they were in high school. Dr. Ford and Kavanaugh both made their cases to the Senate on September 27, 2018. Kavanaugh forcefully denied the allegations and Dr. Ford stated that she was $100 \%$ certain that Kavanaugh had assaulted her. After a very brief investigation by the FBI that could not verify the incident occurred, Kavanaugh was confirmed by a narrow margin of 50-48 by the Republican led Senate committee on October 6, 2018 (Wagner, Ries, Tatum \& Murphy, 2018)

7 House/Senate Agreement. News media stories revealed that previously filed harassment complaints against Congressmen was being paid for by taxpayers and that the accusers had a difficult time getting their allegations heard let alone believed. Thus, the House Ethics Committee called for a swift resolution to negotiations over how to change the system of reporting sexual harassment and other abusive workplace behavior on Capitol Hill so that victims rather than politicians could be protected. (Snell, 2018)
} 
Online Journal of Communication and Media Technologies, 2019

Table 1. Topics in Order of Importance: American people vs. President Trump

\begin{tabular}{|c|c|c|}
\hline 2018 NBC/Wallstreet Journal Poll & vs & Trump Tweets \\
\hline Improving economy/record low unemployment & & The Mueller probe \\
\hline Mass shootings & & Separation of families/immigrants seeking asylum \\
\hline Separation of families/immigrants seeking asylum & & Improving economy/record low unemployment \\
\hline Natural disasters & & Natural disasters \\
\hline The year of the woman in congress & & Tariffs and trade negotiations \\
\hline Tariffs and trade negotiations & & Mass shootings \\
\hline The Mueller probe & & The MeToo movement \\
\hline The MeToo movement & & The year of the woman in congress \\
\hline
\end{tabular}

Table 2. Trump's Most Tweeted About Topics

\begin{tabular}{lc}
\hline Topics & Total number of tweets \\
\hline Improving economy/record low unemployment & 51 \\
Mass shootings & 28 \\
The separation of families/immigrants seeking asylum & 65 \\
Natural disasters & 34 \\
The year of the woman in congress & 8 \\
Tariffs and trade negotiations & 31 \\
The Mueller probe & 122 \\
The MeToo movement & 20 \\
\hline
\end{tabular}

Table 3. Trump's Prevalent Stances on Eight Topics in 2018 NBC/Wallstreet Journal Poll

\begin{tabular}{ll}
\hline Topics & Trump's stance/tone \\
\hline Improving economy/record low unemployment & The Victory Lap \\
Mass shootings & I'm sorry for your loss, but here's what could've \\
The separation of families/immigrants seeking asylum & Teen done better \\
Natural disasters & You'll get through this but, don't let a little bad \\
The year of the woman in congress & weather stop you from voting! \\
Tariffs and trade negotiations & Hey, we (Republicans) won too you know! \\
The Mueller probe & One unfair tariff deserves another \\
The MeToo movement & A total hoax launched by the Democrats! \\
& What issues? You're (women) totally better off \\
\end{tabular}

topics that emerged from the $2018 \mathrm{NBC}$-Wallstreet Journal poll of issues most prevalent to the American people despite not being exactly aligned in order of importance.

\section{RQ2 Which Topics Did President Trump Tweet about Most in 2018?}

As Table 2 reveals, Trump tweeted most about the Mueller Probe in 2018, a total of 122 times during the specified times, which spanned a total of 18 weeks across nine major Mueller Probe events. Recall a total of two weeks of tweets per event was collected. His second most tweeted topic was about the separation of families/immigrants seeking asylum with a total of 65 tweets. His third most tweeted topic was regarding the improving economy and/or low unemployment rate. Interestingly, an entire year of tweets were examined for the latter topic, which yielded only 51 tweets in comparison to Trump's top two tweeted about topics.

\section{RQ3 What was President Trump's Stance Regarding the Eight Topics Stemming From the 2018 NBC/Wallstreet Journal Poll?}

As Table 3 demonstrates, President Trump had some prevalent stances regarding the eight topics stemming from the 2018 NBC/Wallstreet Journal poll.

However below are more in-depth details of Trump's stances on each topic:

\section{Topic 1 stance: The improving economy/record low unemployment}

The President spent the majority of his 51 tweets describing the economy as the best, greatest, and most booming economy in history. He spoke of the record low unemployment 
rate and job creation not in the context of how helpful it was to millions of Americans and how it would benefit them in their everyday lives but more in a bragging, let me pat myself on the back type of way. Additionally, he also tweeted and/or referenced any prominent individual who gave him credit for improving the economy. One tweet praised Trump tremendously and criticized the economy of his predecessor, President Trump saying that under President Obama, America saw the worst and slowest economic recovery since the Great Depression and it only took Trump six months to get to a $3.7 \%$ rate for unemployment (the lowest number since 1969). President Trump seemed to revel in such words of support as he openly agreed and likewise also openly criticized former President, Barack Obama for his terrible deals on trade agreements like NAFTA, which he says took jobs away from the United States and sent them overseas. President Trump also boasted about how jobs for minorities particularly African Americans had improved tremendously under his administration and that consequently more of them should be voting Republican rather than Democratic. Thus, approximately 40 out of the 51 tweets discussed the aforementioned things. The other 11 tweets collected during this time endorsed and/or supported some of the Republican candidates running for either Senate or the House during the November 2018 midterm elections. Each time, Trump cited that those candidate's goals aligned with his as it related to the economy and that they would bring jobs, jobs, and more jobs just like him.

\section{Topic 2 stance: Mass shootings}

President Trump offered his condolences to the families in all the four shootings examined. His most sympathizing tweets came after the Stoneman Douglas shooting in Parkland, Florida on Valentine's day. There were approximately six tweets of prayer/ condolences/sympathy after the Stoneman shooting compared to two for the Sante Fe shooting and one for the Tree of Life Synagogue shooting. In addition to his sympathy, Trump and the first lady visited with the families of the victims and he offered his full support to all the Governors of each state and cities where the shootings occurred. Trump also suggested that gun law legislation should be examined in wake of the Stoneman Douglas shooting and that perhaps teachers should be armed in order to make schools safer. Trump seemed to change the subject from sympathy and condolences to criticism when he said that some first responders in the Stoneman Douglass shooting should've arrived sooner on the scene so that some fatalities could've been avoided. Additionally, he called out the FBI and neighbors and classmates of the Stoneman Douglas shooter for failing to pay attention to the warning signs that he might act violently. As stated, only two tweets appeared in the key word search regarding the Santé Fe shooting, both tweets offered concern and sympathy. In the Tree of Life Synagogue shooting, in two of his seven tweets, Trump criticized/condemned the attack on the Jewish American's place of worship as "evil" and "anti-Semitic" and called on the world to unite to help conquer it.

\section{Topic 3 stance: Separation of families/immigrants seeking asylum}

Most of Trump's 65 tweets regarding the separation of immigrant families at the Southern border criticized the Democrats. Specifically, approximately 31 of the 65 tweets accused Democrats of putting the lives of Americans in danger through their push for "open borders" rhetoric and their provision of sanctuary cities for immigrants seeking asylum. In contrast Trump tweeted that under current border circumstances, Americans were at a grave risk of danger from violent immigrants entering the country via the southern border. Thus, he said, it was extremely important to secure the border. The President condemned any individual/entity against border patrol and/or that embraced asylum/sanctuary for immigrants. On the other hand, Trump was very supportive of the 
work being done by those working at the border and to the men and women working to round up illegal immigrants in sanctuary cities.

After the first child dies at the border, Trump makes no mention of the child's death. No condolences or concern is expressed. Instead, there's a string of 12 of that periods 24 tweets in which the President continues to criticize the Democrats stance on border safety and their refusal to give him funds to build his wall to secure the southern border. A few other Trump tweets openly criticized the media for their coverage of immigration and former President Barack Obama's handling of immigration during his administration. Trump accused the media of overdramatizing the situation and stated that Obama held children and families in unsafe/unfit places and didn't get half the criticism that he does.

After a second child dies at the border, Trump does mention the death of the child. However, he blames the death on the Democrats, and he deflects any responsibility. In fact, Trump takes the time to reiterate that the father of the child openly said that his child was sick before they were in the custody of the border patrol and that it wasn't their fault his child had died. This time period of tweets regarding the separation of families/immigration also saw the President's highest number/ratio of tweets referencing immigrants as "violent" and the need to keep and get them out. In fact, five of the 16 tweets after the second child's death attacked immigrants even though two kids had just died at the border.

\section{Topic 4 stance: Natural disasters}

With a total of 34 tweets, Trump like with the mass shootings, offered his sympathy/condolences to the victims affected by Hurricanes Florence and Michael and the California wildfires and he commended al of the first responders, including medics, police officers, and firefighters. Additionally, there was a very quick response by the President to offer government assistance to the governors of each state.

Trump also utilized the opportunity of the natural disasters to recognize politicians who were up for election in the states of Florida and Georgia. Specifically, he often tied in how well they were dealing with the natural disasters and that consequently they'd be great candidates to elect to the respective offices they were running for. Lastly, Trump spent a couple of tweets scorning California Forest Management alleging that they could do more to prevent and/or stop the California fires from occurring. He called their actions "poor" and accused them of "gross mismanagement of the forests" and if they didn't remedy their actions, they would receive less federal aid.

\section{Topic 5 stance: The year of the woman in congress}

Gathered from mid-term election day, November $6^{\text {th }}-20^{\text {th }}$, only eight tweets regarding the results of the mid-term election were found using the keywords congress, women, midterm election, senate, house of representatives, Democrats, and Republicans. Of those tweets, none made mention of the historic results of November $6^{\text {th }}$ in the context that it yielded the election of more women and people of color to Congress than ever before. In its place, President Trump chose to discuss the number of seats picked up by the Republicans in the Senate and to congratulate himself for stomping on behalf of some of the winners. He also announced that a press conference would be held to highlight their (Republicans) mid-term election gains. A conference he felt was necessary as the media seemed to be paying more attention to the seats picked up by the Democrats in the House of Representatives rather than the Republican gains in the Senate. Finally, regarding the controversial Florida governorship race between Andrew Gillum (D) and Ron DeSantis 
(R), Trump accused the Democrats of trying to steal votes and said that he was sending lawyers to Broward County in Florida to oversee the vote count process.

\section{Topic 6 stance: Tariffs and trade negotiations}

17 of 31 tweets during this time period paint the topic of tariffs and/or trade negotiations as one of importance to President Trump as he describes his administration as one doing all things right in contrast to the previous Obama administration who he says cost Americans thousands of job under his bad trade agreements. As one of his top campaign promises to bring jobs back to the U.S., Trump seems very passionate about holding countries such as China accountable and isn't apologetic about increasing tariffs on them. Some of his tweets openly criticize Democrats and anyone else who questions his use of tariffs to counter unfair tariffs on the U.S. Additionally, seven of 31 tweets, Trump commends countries/leaders such as the European Union, who are working amicably with the U.S. in trade talks and in at least four tweets he calls out countries like Turkey who he thinks is taking advantage of the U.S.

\section{Topic 7 stance: The Mueller probe}

With almost twice as many tweets as his $2^{\text {nd }}$ most tweeted topic during 2018, the Mueller Probe seemed to be front and center on the mind of the President. Of the 122 tweets collected and examined, 54 referred to the Mueller Probe as a baseless hoax/witch hunt and/or declared there was no collusion between the Russians and the Trump 2016 presidential campaign.

There was also a considerable number of tweets that called for the energy being spent on investigating him and his campaign to be refocused towards taking a second look at "crooked Hillary Clinton" and the Democrats. Trump alleges that Clinton's email scandal wasn't handled properly by then FBI Director, James Comey and/or others in the FBI and that she got off easy even after erasing emails and mishandling confidential information via a private email server. He also pointed out that he believes that somehow Clinton and/or the Democrats helped to launch the baseless Russia probe in retaliation to losing the 2016 presidential election in which many were certain Clinton would win. Consequently, 39 of the 122 tweets about the Mueller probe were dedicated to calling out/criticizing and/or blaming Clinton and the Democrats for the various reasons already mentioned. 17 times, the President attacks and/or criticizes the Russia probe's leading investigator, special counsel, Robert Mueller going after his character and alluding that he has conflicts of interest and should step down from the investigation.

\section{Cohen raid, guilty plea, individual 1, sentencing}

Specific to President Trump's former personal lawyer Michael Cohen's apartment raid, guilty plea, reference to President Trump as Individual 1, and his sentencing; there were 55 total tweets centered around those events. Of those 55 tweets, only one references the Cohen Raid specifically in which Trump says it's unthinkable and bad to raid a lawyer's office for information. The President's other tweets surrounding the raid aggressively go after James Comey, the former FBI director he fired because of his handling of the Clinton email investigation. In fact, he calls it an honor to have fired Comey and says he's an untruthful slime ball that will probably go down in history as the worst FBI Director in history. Approximately 20 tweets were specific to the Cohen raid time period, 19 times Comey is criticized and six times the Russia probe is referenced as corrupt/baseless.

After Cohen pleads guilty, there are three times in which Trump defends Cohen as a good person whom he likes and respects. However, after Cohen says that he made an illegal campaign payment to Stormy Daniels (hush money to not reveal she had a 
relationship with President Trump) at the direction of "Individual 1", which many suspected at the time and it was later revealed was allegedly President Donald Trump; the tweets about Cohen changed. Trump accuses Cohen of making up lies to get a further reduced sentence and claims that Cohen as his lawyer is liable for the transaction if it was indeed illegal. After Cohen is sentenced to three years in prison, the President continues to deflect responsibility of the Stormy Daniels' payment off him and completely on to Cohen insisting that he was only following the advice of counsel. In one tweet, Trump references Cohen as a "rat" in relation to his agreement to cooperate with federal authorities. Overall, Trump mentions and addresses Cohen but spends most of his tweets during this time criticizing the probe, the investigators leading it, the media's coverage, and questions why Hilary Clinton and the Democrats aren't being reinvestigated.

Paul Manafort, former Trump campaign manager

Of the 45 tweets during this time period, only one tweet mentions Manafort by name. In this tweet, President Trump expresses how badly he feels for Paul Manafort and his wonderful family and that he is so brave to refuse to give in/break to get a plea deal unlike Michael Cohen. Almost all the other tweets during this period are more of the samemore attacks on the media, Clinton, the Democrats, Obama, and now the Department of Justice (DOJ) and the FBI. Trump accuses Obama of illegally spying on his 2016 presidential campaign. He alleges that the DOJ is corrupt because some of the individuals who work there have ties to Russia and of course that Mueller is corrupt because he's best friends with the fired and former, FBI Director, James Comey.

\section{Russian interference social media}

In response to the 13 Russians and entities indicted for using social media to influence the 2016 Presidential Election, President Trump responds by not criticizing the Russians or their leader, Vladimir Putin. Instead, he says that he never said the Russians didn't meddle in the 2016 elections but that it could've been any other country including China and regardless if they interfered or not, there was no efforts by the Trump campaign to collude with them. Additionally, Trump makes it a point to say that Obama is to blame if the Russians did indeed meddle in the election because he was the one in power. Accordingly, of the 14 tweets during this time period, five stated that the interference by the Russians had no impact and four blamed Obama. The other tweets continued to call the Russia probe a hoax and declared that there was no collusion by the Trump campaign with the Russians.

Russian interference indicted for hacking Democratic National Committee computers

Only eight tweets were collected during the two-week period following the indictment of 12 Russian officials who worked for the Russian Government's military intelligence unit. Allegedly, these officials hacked the computers of the DNC during the 2016 Presidential Campaign, stole and leaked that information (emails) in order to damage then Democratic presidential candidate, Hillary Clinton. President Trump never mentions the 12 officials and/or their indictment. Additionally, he never calls out Putin or any other Russians nor does he express concerns of their interference with American Democracy. However, he continues to criticize the Russian investigation and the legitimacy of how it even began. Notably, Trump says that he had to beat the Bush and Clinton Dynasty to get into office and now that he's been elected the Russian witch hunt looms over his presidency and all the good things that he's done while president is being overlooked as a result. 


\section{Topic 8 stance: The MeToo movement}

A total of 20 tweets were found during this time period none of which specifically mentioned the phrase "MeToo". However, the events that were examined were a part of and/or as a result of the movement. Recall the Women's March which took place on January $20^{\text {th }}$. It was the second annual women's march, which was originally created in protest to the 2016 election of President Donald Trump and to speak out against unfair and/or unequal treatment of women in the workplace, etc. After a period of two weeks, only one tweet emerged in which the President referenced the Women's march. In it Trump said that it was a beautiful and perfect day for all women to march because they should be celebrating the historic milestones and unprecedented economic success and wealth creation that has happened to them under his administration and that female unemployment is the lowest it's been in 18 years.

President Trump addressed none of the concerns that women had about his policies, about closing the equal pay gap between women and men, and/or women's healthcare concerns. Instead his tweet seemed to say you should be thanking me for improving your lives. A few other tweets pulled up with the key words but weren't related to the March.

In the aftermath and during the hearings of President Trump's supreme court nominee, Brett Kavanaugh and Dr. Christine Blasey Ford, the President offers his full throttle support of the Judge and says that the allegations against him are "totally uncorroborated" and calls Kavanaugh's testimony powerful, honest, and riveting. He also criticizes and blames the Democrats for harsh and unfair treatment of Judge Kavanaugh and claims it's just another tactic to obstruct and delay one of his appointees. Precisely six of 14 tweets praised Kavanaugh, five criticized the Democrats, other tweets pointed out that even women supported Kavanaugh's nomination, some referenced the media's handling of the hearing as "fake news" and two praised the final Senate confirmation of Kavanaugh's appointment. Trump wasted no time in swearing in Judge Kavanaugh to the U.S. Supreme Court and criticized the New York Times newspaper for not including the confirmation on its front page. Kavanaugh's confirmation was on October $6^{\text {th }}$ which crossed over the two-week Kavanaugh/Dr.Ford hearing tweets gathering of September $27^{\text {th }}$ to October $11^{\text {th }}$. Confirmation from October $6^{\text {th }}$ to the $20^{\text {th }}$ yielded only five tweets, which were the same as the last of the previous period's tweets. Again, the emerging theme was praise of Kavanaugh and people/women in support of Kavanaugh, criticism of the fake media, and praise of the senate. Finally, as it relates to the House/Senate agreement to change old rules regarding sexual harassment and discrimination on Capitol Hill from December $12^{\text {th }}-16^{\text {th }}$, there is no mention by Trump of this topic.

\section{DISCUSSION / CONCLUSION}

This study reveals that what the American people deemed as most important to them in 2018 was not necessarily on the same page as President Trump at least not according to the NBC/Wallstreet Journal poll. The top three things on the mind of the people was the economy, mass shootings, and immigration. For the President, it was the Mueller probe, immigration, and then the economy. Therefore, it can be said that at least two of the topics/events in each one's top three match up although they are not in the same order of importance. However, even though the frequency of Trump's tweets didn't align completely with the rank order in the poll, the mere fact that he mentioned/tweeted about all events/topics viewed as relevant to the American people is an indication that some Trump influence may have taken place. If there had been an absence of tweets collected across most of the topics, that might indicate a lack of connection between the 
mindset/agenda of the President and the American people. This direct correlation is an indication that what Trump was tweeting may have indeed influenced what Americans were thinking about throughout the year which may have swayed the topics that they ultimately named as most important to them. As previous studies have examined the impact of Trump's tweets on mainstream media and found direct links between the front pages of major newspapers and the President's messages via Twitter (Perez-Curiel \& Naharro, 2019) and the thought processes/writings of political journalists and editors (Parmelee, 2019); this study also provides a correlation between what the American people deemed as most important to them in 2018 with Trump's tweets during that same year.

However, if this study had only explored the frequency of Trump's tweets and not the context of them, a complete view of the President's agenda would not have been revealed. In addition to the frequency of the tweets, the themes/thesis of the topics were examined. It revealed that even though Trump tweeted about all the issues in the 2018 poll, his perspectives on them were not what one might expect from the President of the United States. In fact, Trump rarely utilized his Twitter platform regarding those most central topics to be a unifier, a comforter, or a leader who reaffirms and reinforces the power of democracy. Instead, during most of the events that he tweeted about in 2018, the President tended to be self-serving and praising of those in agreement with his decisions regarding the economy, immigration, trade and government overall and critical to any of those in opposition. Except for Trump's tones of sympathy during the periods of mass shootings and natural disasters, there's rarely any traditional, presidential tones of hope and encouragement. Instead, recall in the wake of the Stoneman Douglas school shooting and the death of the two children at the southern border, the President utilized those moments to criticize the response times of first responders and to blame the Democrats for the death of the immigrant children. Even when women marched a second time on Washington (first time was during his inauguration into office in 2017) asserting they had issues that needed to be examined like unequal treatment in the work place, healthcare, and sexual harassment, the President essentially responded and deflected that women were better off economically than they'd ever been due to the works of his administration increasing their wages. Ultimately as the 122 out of 359 tweets on the Mueller probe revealed, Trump seemed much busier defending himself and attacking those leading the Russia investigation than focused on the other pertinent issues concerning Americans.

2020 is the next upcoming presidential election and many opposing candidates to President Trump, over 20 Democrats, have made their announcements to run via social media. So, it seems the presence of the alternative medium is here to stay in politics. Learning how to effectively use it and the impact of using it will continue to be an unfolding discourse of discussion in the realm of political communication. Donald Trump won the 2016 presidential election when many major polls released by major news outlets/polls had him losing to Hilary Clinton by several points. Twitter was one of his major reasons for being victorious in that election and it continues to be his chief means of communicating while in office. This study demonstrates that during 2018 it didn't seem that President Trump's platform of things most important matched up exactly with the American people. Nonetheless, it did show an extreme connection. Will it matter in the large political scope of things? Perhaps only a successful presidential bid for re-election in 2020 will determine how powerful President Trump's Twitter platform has been while in office. 


\section{Limitations of This Study}

All of President Trump's 2018 tweets were not utilized in this study and/or sample of tweets. Therefore, some pertinent tweets regarding the specified topics included in the NBC/Wallstreet's 2018 poll may have been excluded due to the study's designated time frames of analysis.

In addition to the frequency of Trump's tweets, this study examined the stance behind President Trump's tweets. However, NBC/Wallstreet's 2018 poll only measured what was important to Americans but didn't ask for elaboration as to why those issues were important. It would've been interesting to know why they felt so strongly about the numerous issues in the poll and if those feelings varied according to their individual political affiliation. Additionally, it would've been important to know if the ranking of salient issues/topics varied according to political affiliation and if Republicans aligned more with President Trump than Democrats and Independents.

\section{Future Implications}

As the literature review points out, a continued study of the influence and relationship of social media and politics must be examined as the last two major presidential elections have relied on it heavily to communicate with various constitutes. Even a foreign country like Russia whose officials were indicted for allegedly utilizing U.S. social media platforms to spread negative advertisements about Hilary Clinton recognize how heavily Americans rely on social media to gather their information as they allegedly spent much time and energy to influence the outcome of the 2016 presidential election. But like this study, it is difficult to establish a true impact of social media by influencers on followers especially when those like President Trump has millions of followers. Therefore, measurable usages of social media in conjunction with agenda-setting must be examined together when possible in order to measure the full impact of social media on political election outcomes and on people's lives.

\section{REFERENCES}

Alonso-Muñoz, L., \& Casero-Ripollés, A. (2018). Political agenda on Twitter during the 2016 Spanish elections: Issues, strategies, and users' responses. Communication \& Society, 31(3), 7-25.

Anderson, B. (2017). Tweeter-in-Chief: A content analysis of President Trump's tweeting habits. Elon Journal of Undergraduate Research in Communications, 8(2), 36-47.

Beavers, O., \& Thomsen, J. (2019). A timeline of the Mueller probe's biggest Developments. Retrieved from https://thehill.com/policy/national-security/422923-a-timeline-of-themueller-probes-biggest-developments

Bureau of labor statistics: Overview of BLS statistics on unemployment. (2019). Retrieved from https://www.bls.gov

Dann, C. (2018). Mass shootings, economy ranked as most significant news event of 2018. Retrieved from https://www.nbcnews.com/politics/meet-the-press/mass-shootingseconomy-ranked-most-significant-news-events-2018-n948201

Desilver, D. (2018). A record number of women will be serving in the new congress. Retrieved from http://www.pewresearch.org/facttank/2018/12/18/record-numberwomen-in-congress/

Hegarty, A. (2018, June 27). Timeline: Immigrant children separated from families at the border. USA Today. Retrieved from https://www.usatoday.com

Johnson, C. A., \& Hawbaker, K. (2019, March 7). \#MeToo: A timeline of events. The Chicago Tribune. Retrieved from https://www.chicagotribune.com 
Johnson, S. J. (2018). Donald Trump, disruptive technologies, and Twitter's role in the 2016 American presidential election. Widener Law Journal, 27(1), 39-82.

Keith, T. (2016). Commander-In-Tweet: Trump's social media use and presidential media avoidance. Retrieved from https://www.npr.org/2016/11/18/502306687/commanderin-tweet-trumps-social-media-use-and-presidential-media-avoidance

Lee, J., \& Xu, W. (2018). The more attacks, the more retweets: Trump's and Clinton's agenda setting on Twitter. Public Relations Review, 44(2), 201-213. https://doi.org/10.1016/j.pubrev.2017.10.002

Levine, M. (2019). The Russia probe: A timeline from Moscow to Mueller. Retrieved from https://abcnews.go.com/Politics/russia-probe-timeline-moscow-mueller/story?id=574 27441

McCombs, M., \& Shaw, D. L. (1972). The agenda-setting function of mass media. Public Opinion Quarterly, 36, 176-187. https://doi.org/10.1086/267990

Parmelee, J. H. (2013). The agenda-building function of political tweets. New Media and Society, 16(3), 434-450. https://doi.org/10.1177/1461444813487955

Pérez-Curiel, C., \& Naharro, P. L. (2019). Political influencers. A study of Donald Trump's personal brand on Twitter and its impact on the media and users. Communication \& Society, 32(1), 57-75. https://doi.org/10.15581/003.32.1.57-76

Rodríguez, J., \& Jin, B. (2018). The Mueller indictments so far: Lies, trolls and hacks. Retrieved from https://www.politico.com/interactives/2018/interactive_muellerindictments-russia-cohen-manafort/

Snell, K. (2018). Congress to make members pay out of pocket for sexual harassment settlements. Retrieved from https://www.npr.org/2018/12/12/676209258/congress-tomake-members-pay-out-of-pocket-for-sexual-harassment-settlements

Stacks, D. (2011). Primer of Public Relations, $2^{\text {nd }}$ Edition. New York, New York: The Guilford Press.

Tariff timeline for U.S. imports and exports. (2018). Retrieved from https://www.scarbrough-intl.com/trump-tariff-timeline/

Wagner, M., Ries, B., Tatum, S., \& Murphy, P. (2018). Brett Kavanaugh and Christine Blasey Ford testify on sex assault allegations. Retrieved from https://www.cnn.com/ politics/live-news/kavanaugh-ford-sexual-assault-hearing/index.html

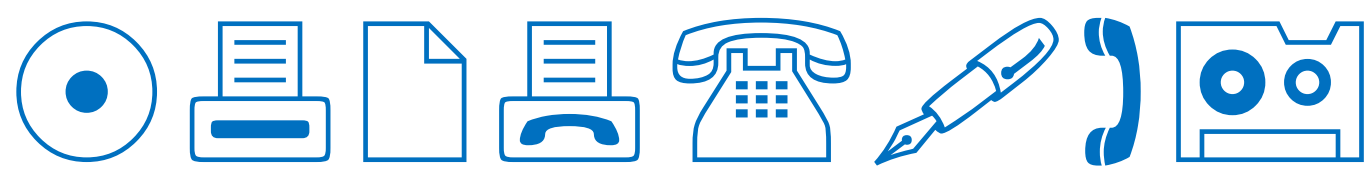

